\title{
Dociekania
}

\section{Walka z hałasem ulicznym w międzywojennej Warszawie. Moda czy konieczność? ${ }^{1}$}

Sławomir Łotysz

TEKSTY DRUGIE 2020, NR 2, S. 324-344

DOI: $10.18318 /$ td.2020.2.20 | ORCID: 0000-0003-4426-6401

W 1935 roku felietonista lwowskiej „Chwili” zauważał ironicznie, że metropolie i niektóre dopiero aspirujące do tego miana miasta na całym świecie „wprost lubowały się w ustawicznym szumie najrozmaitszych dźwięków i głosów, i im krzykliwsza, huczniejsza, wrzaskliwsza była wielkomiejska ulica, tym większe i ważniejsze wydawało się sobie miasto"2. Sarkastyczny charakter tej uwagi jest oczywisty, zwłaszcza że autor poczynił ją w kontekście ukazujących się wówczas dość często na łamach prasy krajowej doniesień o różnego rodzaju inicjatywach antyhałasowych podejmowanych w Nowym Jorku, Londynie czy Berlinie. Celem tych akcji było ograniczenie hałasu ulicznego, którego źródłem był głównie ruch pojazdów mechanicznych.

1 Artykuł stanowi dwugłos z tekstem Magdaleny Zdrodowskiej Miejskie epidemie głuchoty - brzmienie nowoczesności, który ukazał się na łamach "Tekstów Drugich" w numerze 1/2020.

2 Walka z hałasem, "Chwila” 1935 nr 209, s. 3.
Sławomir Łotysz

- dr hab., prof. PAN, pracownik Instytutu Historii Nauki PAN. Historyk techniki, przewodniczący International Committee for the History of Technology (ICOHTEC). Interesuje się społecznymi, kulturowymi i politycznymi aspektami postępu technicznego. Ostatnio opublikował: Fabryka z darów. Penicylina za żelazna kurtyną 19451954 (2020).s.lotysz@ gmail.com 


\section{Uciążliwość czy atrybut postępu?}

Lekarze i filozofowie od dawna świadomi byli negatywnego wpływu, jaki hałas wywiera na ciało i duszę człowieka. Już Kant i Goethe uważali, że zgiełk w każdej postaci jest szkodliwy dla zdrowia. Artur Schopenhauer nazywał go torturą dla człowieka i mordercą myślenia w ogóle . Z $^{3}$ kolei Walter Platt, angielski lekarz higienista, już pod koniec XIX wieku zwracał uwagę na destrukcyjny wpływ zgiełku miejskiego na zdrowie psychiczne. Choćby nawet był to hałas o nieznacznym natężeniu, to jego ciągły charakter mógł stanowić przyczynę dużych niedogodności, jak „nieprzerwane spadanie kropli w jedno miejsce". Platt porównywał takie działanie do „uderzania młotkiem w nerwy słuchowe"4. W pierwszej dekadzie XX wieku, gdy ulice europejskich miast zaczęły szturmem zdobywać samochody, do walki o ciszę włączył się niemiecki filozofTheodor Lessing. Ostrzegał, że „przemożne zwycięstwo”, jakie „szalejący, hałaśliwy, klekoczący, śmierdzący benzyną silnik" osiąga nad człowiekiem, doprowadzi wkrótce do „przeobrażeń biologicznych” daleko wykraczających poza to, do czego rodzaj ludzki byłby w stanie się przystosowaćs.

Już w połowie XIX wieku starano się hałas bądź to ograniczyć, bądź oswoić. O ile to pierwsze obejmowało głównie środki prawne (by wspomnieć zakaz trzaskania z bicza przez woźniców wprowadzony w Norymberdze w 1858 roku), o tyle oswajanie zgiełku polegało na zracjonalizowaniu jego obecności jako nieodłącznego atrybutu postępu cywilizacyjnego ${ }^{6}$. A że postęp to rzecz chlubna, każde kolejne pokolenie uważało, że zgiełk, na jaki uskarżali się antenaci, był niczym w porównaniu z hałasem, z którym sami musieli sobie radzić - był jak „flet wobec działa”, by zacytować Rudolfa Lothara, berlińskiego felietonistę z początku XX wieku? . Niektórzy szli jeszcze dalej. Edward Steinberger, lwowski prawnik, a zarazem muzykolog i pianista, choć podejmowane tu i ówdzie akcje przeciwhałasowe nazywał chwalebnymi, to ich inicjatorów przekonywał, że hałas stał się nieodłącznym elementem życia, „, niejako jego

3 Najbardziej dokuczało mu trzaskania z bicza przez woźniców, ale hałas z tym związany najwyraźniej dawał się we znaki również innym - w 1858 roku praktyka ta została zakazana przez władze miejskie Norynbergi. Zob. Walka hałasem ulicznym dzisiaj a dawniej, „Kurier Warszawski" 1934 nr 356, s. 6.

4 Wpływ miasta na organizm ludzki, "Prawda" $1888 \mathrm{nr} 45$, s. 537.

5 T. Lessing Der Lärm. Eine Kampfschrift gegen die Geräusche unseres Lebens, J.F. Bergmann, Wiesbaden 1908, s. 49.

6 Uszanujmy spokój sq̨siadów, "llustrowana Republika” 1932 nr 45, s. 8.

7 Wrzawa wielkomiejska, "Ziarno" 1908 nr 14, s. 1. 
wklęsłym zwierciadłem akustycznym"8. Pewnie dlatego nie brakowało kompozytorów, dla których zgiełk stał się inspiracją, a nawet tematem twórczości, by wspomnieć Krzyki Paryża z 1857 roku, Pacific 231 czy Odlewnię stali z lat 20. XX wieku, których kompozytorzy - odpowiednio Jean-Georges Kastner, Arthur Honegger i Aleksandr Mosołow - za pomocą muzycznych środków wyrazu starali się oddać brzmienie miasta, pędzącej lokomotywy i fabryki.

Od początku XX wieku wobec coraz większej świadomości szkodliwych skutków nadmiernej kakofonii dźwięków w rozwiniętych krajach Zachodu, przede wszystkim w Stanach Zjednoczonych, Wielkiej Brytanii i Niemczech, zaczęły powstawać organizacje i instytucje stawiające sobie za cel walkę z hałasem. Zaczęto badać naturę zgiełku oraz jego wpływ na zdrowie człowieka. Aby w sposób obiektywny określić skalę tego oddziaływania, przyjęto jednostkę miary, skonstruowano przyrządy w niej wyskalowane i doświadczalnie wyznaczono wartości graniczne, powyżej których hałas wyraźnie szkodził zdrowiu fizycznemu i psychicznemu człowieka. Równolegle podejmowano doraźne kroki - głównie organizacyjne i legislacyjne - w celu ograniczenia poziomu zanieczyszczenia środowiska akustycznego człowieka: w mieszkaniu, w miejscu pracy, a przede wszystkim na ulicy.

Celem mojego artykułu jest przedstawienie debaty na temat hałasu i potrzeby walki z nim, jaka toczyła się w międzywojennej Polsce. Temat ten umykał jak dotąd uwadze badaczy, stąd w pracy oparłem się głównie na materiałach źródłowych z epoki, przede wszystkim na doniesieniach prasowych, a także artykułach z czasopism medycznych oraz technicznych.

\section{Świat się wycisza}

Tak jak trzaskanie z bicza było symbolem zgiełku ulicznego w połowie XIX wieku, tak w pierwszych dekadach XX stał się nim samochodowy klakson. O ile jednak w Norymberdze, a zapewne i w innych miastach, można było mandatami zmusić woźniców, by poganiali konie w ciszy, o tyle zakazu stosowania klaksonów, trąbek i dzwonków, jakimi posługiwali się kierowcy samochodów, nie można było wprowadzić z dnia na dzień. Kodeksy drogowe w większości krajów europejskich zobowiązywały szoferów do ostrzegania innych uczestników ruchu o podejmowanych manewrach. Nagła zmiana przepisów mogła mieć więc przykre skutki przede wszystkim dla pieszych. Toteż, aby przygotować do niej wszystkich uczestników ruchu drogowego,

8 E. Steinberger Polifonia życia codziennego a muzyka hałasu , "Chwila” 1935 nr 5721, s. 9. 
w połowie lat 30. w wielu miastach europejskich organizowano tzw. tygodnie ciszy. Podczas takiej poprzedzonej kampanią propagandową akcji kierowcy, motocykliści, woźnice i tramwajarze mieli zakaz korzystania z sygnalizacji dźwiękowej. Pieszych nakłaniano, by jezdnie przekraczali wyłącznie w miejscach do tego wyznaczonych, najczęściej w pobliżu skrzyżowań. Od wszystkich zaś oczekiwano wzmożonej czujności i odpowiedzialności.

$\mathrm{Na}$ początku 1935 roku eksperymenty tego rodzaju przeprowadzono w Rzymie, Mediolanie i Trieście. W tym ostatnim, po stwierdzeniu, że ruch uliczny „nie cierpi na nieużywaniu” klaksonów i trąbek, zakaz ich stosowania poza przypadkami absolutnej konieczności przedłużono bezterminowo?. Znacznie większy zasięg miały tygodnie ciszy zorganizowane latem 1935 roku we Francji i w Niemczech. Nie dość, że były to przedsięwzięcia ogólnokrajowe, to jeszcze traktowały problem miejskich hałasów bardziej kompleksowo. Trwający od 6 do 12 maja tydzień zwalczania zgiełku w Niemczech, ogłoszony przez ministerstwo propagandy, dotyczył przede wszystkim kwestii niedostatecznej izolacyjności akustycznej ścian i stropów ${ }^{10}$. Oprócz akcji rozdawania ulotek popularyzujących stosowanie konstrukcji sprzyjających tłumieniu zbyt głośnych dźwięków zaproponowano powołanie w budynkach wielorodzinnych "komisarzy do zwalczania hałasu”. Z kolei we Francji, gdzie inicjatorem ogólnokrajowego tygodnia ciszy był znany z niechęci do radia pisarz Georges Duhamel, oprócz walki z hałasem ulicznym baczną uwagę zwrócono na problem zbyt głośnej muzyki, której słuchano w mieszkaniach, co szczególnie latem odbywało się na ogół przy otwartych oknach".

\section{Hałas po polsku}

W Polsce świadomość potrzeby zmierzenia się z problemem hałasu ulicznego narastała wraz z kolejnymi doniesieniami na temat inicjatyw antyhałasowych podejmowanych głównie przez największe metropolie w rozwiniętych krajach Zachodu. Od początku lat 30. mieszkańcy Warszawy, głównie głosami publicystów, ale i swoimi własnymi, coraz częściej domagali się podjęcia podobnych akcji w ich mieście. Na ile wynikało to z rzeczywistych potrzeb, a na ile z powodowanego ambicją naśladownictwa, nie wiadomo.

\footnotetext{
9 Godne naśladowania, "Orędownik. Codzienne pismo narodowe i katolickie” 1935 nr 10, s. 2.

10 "Tydzień zwalczania hałasu” w Niemczech, "Dom Osiedle Mieszkanie”" 1935 nr 7, s. 25.

11 Tydzień ciszy we Francji, „Expres Zagłębia” 1936 nr 213, s. 7.
} 
Po części zapewne pod wpływem takich głosów w 1934 roku ministerstwo komunikacji rozpoczęło prace nad projektem przepisów mających na celu walkę z hałasem ulicznym ${ }^{12}$. Studia nad tym zagadnieniem powierzono Związkowi Przedsiębiorstw Komunikacyjnych w Polsce, zrzeszającemu większość podmiotów zajmujących się świadczeniem usług transportowych na terenie kraju. Po zakrojonych na znaczną skalę konsultacjach, w których oprócz zrzeszonych w związku podmiotów brały udział instytucje miejskie oraz organizacje społeczne i zawodowe, powołano Komisję Główną do zwalczania hałasu ${ }^{13}$. W jej skład weszli przedstawiciele ministerstwa komunikacji, ministerstwa spraw wewnętrznych, Komisariatu Rządu, Związku Miast Polskich, Automobilklubu Polskiego oraz pracownicy wyższych uczelni i członkowie różnych organizacji społecznych. Jej przewodniczącym został Alfons Kühn, wieloletni dyrektor Tramwajów Warszawskich i minister komunikacji w latach 1928-1932.

To znamienne, że w Polsce inicjatywa walki z hałasem wyszła ze sfer rządowych, a w dodatku z resortu o charakterze technicznym. Wprawdzie jak dotąd brak jest studiów porównawczych wyjaśniających szczegółową typologię ruchów antyhałasowych w tamtym okresie, ale daje się zauważyć wyraźny podział na oddolne inicjatywy w krajach anglosaskich, Stanach Zjednoczonych i Wielkiej Brytanii, oraz odgórnie zarządzane akcje w kontynentalnej Europie, głównie w Niemczech oraz właśnie w Polsce.

W Ameryce ponadto inicjatorami ruchów antyhałasowych byli przede wszystkim przedstawiciele środowisk medycznych, którzy jako pierwsi, jak się zdaje, problem zdiagnozowali. Natomiast w Europie, a szczególnie we Francji, Włoszech oraz w Polsce, aktywne były kluby automobilowe. Wniosek ten jest o tyle interesujący, że sugeruje zaangażowanie w zwalczanie hałasu tego środowiska, które było najczęściej obarczane odpowiedzialnością za powstanie problemu. Można jedynie zgadywać, że chodziło o zdjęcie z siebie odium sprawstwa jednej z największych plag XX wieku - epoki hałasu, jak wówczas mówiono ${ }^{14}$.

Zarówno skład komisji, jak i jej struktura wyraźnie wskazują, gdzie upatrywano głównego źródła problemów. Z sześciu podkomisji dwie zajmowały się badaniem przyczyn hałasu i propagandą, pozostałe zaś koncentrowały się na zagadnieniach transportowych: opracowaniu przepisów ruchu i sygnalizacji

\footnotetext{
Z. Hrebnicki Hałas w komunikacji i próby jego zwalczania w Polsce, "Inżynier Kolejowy” 1936 nr 12, s. 418 .

Przygotowania do walki z hałasem ulicznym, "Kurier Warszawski” 1934 nr 301, s. 6.

J. Mansell The age of noise in Britain, University of Illinois Press, Urbana 2016, s. 1.
} 
oraz na poszczególnych środkach komunikacji, to znaczy szynowych, kołowych i lotniczych. Grupy te przystąpiły do działania dość energicznie, przy czym za swój główny teren obrały Warszawę jako obszar o największej koncentracji ruchu ${ }^{15}$.

Już podczas posiedzenia w styczniu 1935 roku grupa zajmująca się kwestiami przepisów i sygnalizacji zwróciła uwagę na możliwość zmniejszenia poziomu hałasu ulicznego poprzez zmianę niektórych zapisów kodeksu drogowego. Postulowano między innymi zniesienie uprzywilejowania pojazdów komunikacji miejskiej na niektórych ulicach, jak na przykład na ulicy Chmielnej w Warszawie, gdzie posiadający pierwszeństwo przejazdu autobus był zmuszony do torowania sobie drogi przez zatłoczoną ulicę. Czynił to, rzecz jasna, za pomocą klaksonu, co było głównym źródłem hałasu w całej okolicy.

Podkomisja rekomendowała ponadto zaprowadzenie na skrzyżowaniach sygnalizacji optycznej. W przypadku małego ruchu postulowano zastosowanie dwuramiennych semaforów nastawianych przez policjanta lub jednokolorowych sygnałów świetlnych, a na bardziej ruchliwych skrzyżowaniach sygnalizacji o trzech światłach (czerwonym, żółtym i zielonym) ${ }^{16}$. Sterowanie ruchem za pomocą semaforów lub świateł ulicznych miało zastąpić wymóg sygnalizowania przez kierowców zamiaru wykonania podstawowych manewrów. W Polsce, podobnie jak w innych krajach, kierujący pojazdem miał obowiązek „zawczasu dawać dźwiękowe sygnały ostrzegawcze” przed wyprzedzaniem oraz na skrzyżowaniach dróg'17. Ponadto użycie klaksonu lub trąbki było wymagane wszędzie tam, gdzie droga nie była widoczna na dystansie dostatecznym dla zatrzymania pojazdu, a także w innych okolicznościach, w których „zachodziła tego potrzeba”. Kodeks ten obowiązywał od 1933 roku, ale ten konkretny zapis znajdował się we wszystkich wcześniejszych wersjach przepisów drogowych obowiązujących w II RP. Proponowana zmiana miałaby zatem charakter rewolucyjny.

Postulowano ograniczenie stosowania sygnałów dźwiękowych tylko do sytuacji awaryjnych, gdy ostrzeżenie innych uczestników ruchu było niezbędne. Źródłem takiego sygnału miała być trąbka o „niskim, nierażącym dźwięku". Co charakterystyczne, zalecenia nie definiowały częstotliwości

15

17 Rozporządzenie ministra komunikacji i ministra spraw wewnętrznych w porozumieniu z ministrem spraw wojskowych z dnia 15 stycznia 1933 r. o ruchu pojazdów mechanicznych na drogach publicznych, DzU 1933, nr 9, poz. 55, § 43, pkt 1a i 16. 
ani dopuszczalnego natężenia dźwięku emitowanego przez urządzenie. Ten wyraźny brak precyzji wynikał z wciąż enigmatycznego pojmowania hałasu i dźwięku w ogóle. Członkom komisji zabrakło najwyraźniej wiedzy na temat sposobów pomiaru dźwięku, które na Zachodzie stawały się powoli uznaną praktyką. Co gorsza, nie wiedzieli nawet, że ktoś już w Polsce takie pomiary prowadził (o czym dalej). Opisowe zdefiniowanie zakazanych dźwięków jako „rażących” zakładało konieczność arbitralnej oceny, co jest takim dźwiękiem, a co nie. To z kolei prowadziłoby nieuchronnie do konfliktów między policją a kierowcami. Precyzyjnie określono jedynie to, co można było ująć w sztywne, skodyfikowane ramy i później egzekwować, czyli godziny obowiązywania całkowitego zakazu stosowania sygnalizacji dźwiękowej; postulowano, by cisza nocna trwała od godziny 23 do 6 rano $^{18}$.

Na początku 1936 roku komisja złożyła na ręce Władysława Jaroszewicza, Komisarza Rządu dla m.st. Warszawy, propozycję, aby wzorem zachodnich metropolii zorganizować w stolicy tydzień ciszy. Jako organ administracji w randze wojewody komisarz miał uprawniania do stanowienia takich przepisów w trybie tymczasowym. Zakaz stosowania sygnałów dźwiękowych przez motorniczych, kierowców i dorożkarzy miał obowiązywać od północy do godziny siódmej rano następnego dnia. Kierowcy aut wyposażonych w przełącznik świateł mijania i drogowych mogli ostrzegać innych użytkowników drogi krótkimi błyskami. Ci, których samochody miały światła stałe, musieli zwalniać przed skrzyżowaniem. Za złamanie zakazu groziły sankcje karne.

Pierwszy w Polsce tydzień ciszy, zwany też tygodniem nocnego spokoju, zaplanowany od 6 do 12 lutego 1936 roku, obejmował teren w granicach administracyjnych miasta stołecznego ${ }^{19}$. Początkowo zamierzano połączyć tę akcję z adresowanym do pieszych „tygodniem nauki chodzenia po ulicach"20. $\mathrm{Na}$ taki krok zdecydowano się w Antwerpii dwa miesiące wcześniej - belgijska akcja odbywała się pod hasłem "Otwórzcie oczy, zamknijcie uszy”21. WWarszawie ostatecznie do tego nie doszło, bo w godzinach nocnych, kiedy miał obowiązywać zakaz używania sygnałów akustycznych, większość przechodniów i tak spała.

18

19

20

20

Echa ze stolicy. Życie Warszawy w kilku wierszach, "Echo" 1936 nr 7, s. 4.

Tydzień ciszy nocnej w Warszawie, "Chwila” 1936 nr 6060, s. 12; Ciekawy eksperyment w Warszawie, „Dziennik Bydgoski” 1936 nr 30, s. 4. Komitet przepisów ruchu i sygnalizacji Zwalczanie hałasu ulicznego w Warszawie, "Wieczorny Kurier Grodzieński" 1935 nr 11, s. 2.

21 Tydzień ciszy w Antwerpii, ,Kurier Wileński” 1935 nr 351, s. 4. 


\section{Tydzień ciszy}

Nie brakowało głosów powątpiewających w skuteczność takiej akcji. Twierdzono, że „warszawianin lubuje się w zgiełku i hałasie”, a hałaśliwość „leży w jego temperamencie"22. O tym, jaki był rzeczywiście ten temperament i czy w ogóle stolica przygotowana była na takie eksperymenty, postanowił przekonać się reporter „Dziennika Białostockiego”. Na dzień przed rozpoczęciem akcji przejechał warszawskimi ulicami kilkanaście kilometrów z mocnym postanowieniem, że nie będzie używał sygnałów dźwiękowych. W celu „uniknięcia pokusy” odłączył klakson, a wchodzącą w zakres wyposażenia obowiązkowego trąbkę sygnałową całkowicie zdemontował ${ }^{23}$.

W trasę wyruszył w porze „największego natężenia ruchu”, około godziny siódmej wieczorem. Największe trudności w przejeździe przez miasto sprawiali piesi. Generalnie nie zwracali uwagi na samochód reportera, który zbliżając się do skrzyżowania, nie emitował sygnału dźwiękowego.Zdarzało się, że stali na ulicy, ucinając sobie pogawędkę, albo - na wysokości przystanku oczekując na tramwaj, tak jakby sądzili, „że prędzej go się doczekają stojąc na jezdni niż na chodniku", jak złośliwie zauważył dziennikarz. Ustępowali na bok dopiero w wyniku słownej perswazji reportera wołającego do nich przez otwarte okno lub na dźwięk klaksonów aut stojących za jego samochodem.

Gdy skręcając w wąską ulicę, nieomal wpadł na grupę ludzi wychodzących z kawiarni wprost na jezdnię, usłyszał, że „jedzie jak wariat bez sygnału”. Podobny zarzut, choć w nieco innej formie, usłyszał od policjanta, gdy usiłując skręcić w lewo, zatrzymał się przed strumieniem pieszych przechodzących przez ulicę. Mimo że sygnalizował zamiar skrętu uniesioną strzałką kierunkowskazu, został przez przechodniów zignorowany, w efekcie czego zablokował ruch na skrzyżowaniu. Nadjeżdżający z naprzeciwka autobus „ryczał”, czyli zapewne używał klaksonu, a stojący za autem dziennikarza dorożkarz wołał do niego „z drogi!" Policjant, który, zwabiony tymi odgłosami zjawił się wkrótce na miejscu, zamierzał reportera ukarać za to, że ten chciał „skręcić i wjechać w ludzi nie dając sygnałów ostrzegawczych"24.

Tydzień ciszy, który rozpoczął się kilka godzin później, minął chyba spokojniej niż ten reporterski eksperyment. Najpewniej kierowcy byli do tego stopnia przejęci - by nie powiedzieć: przerażeni - zmianą reguł, że starali

Plotki stołeczne „ „Orędownik. Codzienne pismo narodowe i katolickie” 1936 nr 29, s. 3.

Pół godziny jazdy bez sygnału. Jak rozpocząłem wczoraj "Tydzień ciszy"? „Dziennik Białostocki” 1936 nr 37, s. 5 .

Pół godziny jazdy bez sygnału, s. 5. 
się jeździć z największą uwagą. W ciągu siedmiu nocy na ulicach Warszawy nie doszło do żadnego wypadku, jeśli nie liczyć jednej kolizji samochodu osobowego z wozem konnym, która wydarzyła się i tak kilka minut po godzinie siódmej rano w ostatni dzień eksperymentu.

Podsumowując rezultaty akcji, komisarz Jaroszewicz stwierdzał, że przerosły one jego „pesymistyczne” przewidywania: „Stąd wniosek jasny, że przy wzmożonej czujności i ostrożności tak ze strony pieszych, jak i kierowców jazda bez sygnałów okazała się możliwa"25. Wojewoda wyraził ponadto nadzieję, że planowana na koniec kwietnia kolejna inicjatywa tego rodzaju, ale tym razem obowiązująca całą dobę, również zakończy się powodzeniem i da mu „możność wprowadzenia na stałe zakazu sygnalizowania”. Namawiał kierowców, aby do czasu wydania tych przepisów zastosowali „samorzutnie system niesygnalizowania". Jaroszewicz nie informował ich jednak, jak mieliby się tłumaczyć przed służbami policyjnymi, bo zgodnie z obowiązującym kodeksem drogowym sygnalizowanie akustyczne podstawowych manewrów nadal było wymagane.

Wojewodzie udzielił się zapewne entuzjazm, z jakim niektórzy kierowcy przyjęli inicjatywę tygodnia ciszy. Reporter „Robotnika” odniósł nawet wrażenie, że co ambitniejsi kierowcy nie tylko stosowali się w tym okresie do nowych reguł, ale wręcz za punkt honoru uważali, by - o ile to możliwe wcale nie używać sygnałów dźwiękowych ${ }^{26}$.

Nie wszyscy jednak kierowcy oczekiwali nowych przepisów z równym entuzjazmem. Zdaniem Stanisława Strumph-Wojtkiewicza, redaktora „Kuriera Warszawskiego", tydzień ciszy był jeszcze „jedną pretensją skierowaną wyłącznie do kierowcy”. Tymczasem, „wtłoczony [...] między odpowiedzialność cywilno-karną z jednej strony, a troskę o całość swojego kosztownego sprzętu motorowego - z drugiej” przeciętny automobilista był i tak „najbardziej zdyscyplinowanym elementem ruchu ulicznego", czego nie można powiedzieć o „woźnicach i furmanach, o rowerzystach i publiczności pieszej”27.

Powszechnie przewidywano, że kolejnym krokiem władz będzie zarządzenie tygodnia ciszy całodobowej, a na końcu tej drogi wszystkich czeka permanentny zakaz używania sygnałów dźwiękowych. Spodziewano się również, że zmiana przepisów pociągnie za sobą poważne konsekwencje dla

25 Warszawa zdała egzamin celująco! P. wojewo da Jaroszewicz o tygodniu ciszy nocnej, „Dobry wieczór! Kurier Czerwony" 1936 nr 47, s. 5. 
pieszych, którzy od tej pory nie będą mogli przechodzić przez jezdnię, jak im się żywnie podoba. I podobnie jak kierowcy oni też będą karani w przypadku ignorowania nowych przepisów.

Nietrudno dostrzec w toczącej się wówczas dyskusji zapowiedzi aktualnego do dziś sporu o to, do kogo należy przestrzeń miejska. Pieszy, będąc najsłabszym uczestnikiem ruchu ulicznego, jest jednocześnie jego najbardziej niezależnym, a przez to nieprzewidywalnym elementem. Inaczej niż samochód czy motocykl, które posiadają tablice rejestracyjne umożliwiające ich identyfikację, przechodnie pozostają w dużym stopniu anonimowi. Próba podporządkowania ich regułom funkcjonowania mechanizmu miejskiego była emanacją zakusów władz (lepiej lub gorzej reprezentujących interes społeczny), by kontrolować poczynania jednostki.

Było to zadanie niezmiernie trudne, dotyczyło bowiem chodzenia - jednego z bodaj najgłębiej osadzonych wzorów kulturowych, nieuświadamianej techniki posługiwania się ciałem, by przywołać koncepcję Maussa ${ }^{28}$. Jeśli sądzić na podstawie filmów pokazujących, jak wyglądał ruch na ulicach międzywojennej Warszawy, to jej mieszkańców czekała długa droga: przechodnie i pojazdy mieszają się w niezorganizowaną, rozedrganą i hałaśliwą masę. Poza stolicą wcale nie wyglądało to lepiej. Najgorszy chaos uliczny panował we Lwowie - przynajmniej zdaniem tamtejszego wojewody Alfreda Biłyka. Sytuacja była tak fatalna, że Biłyk stawiał lwowianom za wzór mieszkańców stolicy: „W Warszawie ludzie nie biegają po ulicach, ale chodzą. We Lwowie przechodzień «lezie», a usłyszawszy sygnał - leci"29.

Co znamienne, w oficjalnej narracji lat 30. nie było mowy o hierarchizacji uczestników ruchu drogowego. Choć według projektowanej zmiany przepisów piesi tracili część swojej dotychczasowej wolności, to głównym argumentem za taką zmianą było ich bezpieczeństwo. Jaroszewicz miał tego świadomość, toteż podsumowując rezultaty tygodnia ciszy, apelował do przechodniów, by „pamiętali o kardynalnej zasadzie przekraczania jezdni tylko w pobliżu skrzyżowań"30 . Normą bowiem było w Warszawie przechodzenie ulic w dowolnym miejscu i nie zawsze pod kątem prostym. Przez lata obowiązywania dotychczasowych przepisów piesi przywykli do tego, że nadjeżdżający pojazd sygnalizował swoją obecność. Wprawdzie, jak zauważa

M. Mauss Sociology and psychology: essays, Routledge and Kegan Paul, London 1979, s. 97-123.

P. Wojewoda udzielił szoferom wskazówek. Akcja w celu zapobieżenia nieszczęśliwym wypadkom, „Dziennik Polski" 1939 nr 222, s. 6.

Warszawa zdała egzamin celujaco!, s. 5. 
Foucault, prawo stanowione z czasem zaczyna działać jako norma, co stałoby się udziałem przepisów zakazujących stosowania sygnałów dźwiękowych, ale zanim by do tego doszło, można się było spodziewać wielu kolizji, w których poszkodowani byliby raczej przechodnie niż kierowcy ${ }^{31}$.

\section{Nie tylko klaksony}

Zdaniem wojewody, który powoływał się na bliżej nieokreślone, ale jego zdaniem najwyraźniej wiarygodne badania, klaksony i trąbli stanowiły 60 procent wszystkich hałasów w mieście. Wynikała stąd prosta konkluzja, że nawet po wprowadzeniu zakazu ich stosowania w Warszawie będzie nadal głośno ${ }^{32}$. Również prasa zwracała uwagę na fakt, że przyczyną nadmiernego hałasu nie jest tak naprawdę ruch samochodowy, który wieczorem zamierał do tego stopnia, że stolicę „czuć prowincją”, ale raczej pozostawiający wiele do życzenia stan techniczny infrastruktury transportowej. Problemem były "stare i rozbite taksówki, zużyte tramwaje i szyny" ${ }^{33}$. Cóż z tego, że wręczono kilka „protokołów kierowcom taksówek za „niechcące użycie klaksofonów”, skoro „robotnikom prowadzącym głośne nocne roboty tramwajowe [...] nikt protokółu nie sporządził”, a „nocne tramwaje, choć jeździły bez sygnałów dźwiękowych, niemiłosiernie skrzypiały i wyły na zakrętach".

Wątek hałaśliwego tramwaju w swoim felietonie wykorzystał również Kornel Makuszyński, pisząc na łamach „Kuriera Warszawskiego” jeszcze w trakcie tygodnia ciszy:

Najsroższy jednak zakaz nie da rady głupiemu tramwajowi, jeśli mu się podoba rozdzierającym, diabelskim głosem zapiszczeć na zakręcie.Takie czerwone, ciężkie, staromodne bydle, urządza sobie często niefrasobliwe kawały i kwiczy, jak wieprz odzierany ze skóry. ${ }^{34}$

Makuszyński nie tylko drwił z przesłanek, które legły u podstaw decyzji o ustanowieniu tygodnia ciszy, stwierdzając, że „Warszawa posiada taki sam

\footnotetext{
M. Foucault The History of Sexuality. Volume I: An Introduction, Pantheon Books, New York 1978 S. 144 .

WWarszawie eksperyment się udał, "Chwila” 1936 nr 6072, s. 15.

Dla naszych pań. O większq ciszę w naszej rodzinie, "Dziennik Bydgoski” 1936 r. 30, nr 49, s. 6.

K. Makuszyński O, jaktu cicho, "Kurier Warszawski” 1936 nr 40, s. 5.
} 
obłąkany ruch uliczny, co Nowy Targ", ale też nie wierzył, by akcja pozostawiła jakiś trwały skutek: „tydzień minie i znowu wszystko będzie po staremu. Przez kilka tygodni uczono stolicę chodzić, a dobrzy ludzie chodzą jak dawniej, jakby ich zamroczyło. Tak będzie i z tą błogosławioną ciszą. Dobry to był pomysł, tylko trud daremny" ${ }^{35}$.

Zarząd Tramwajów Warszawskich świadom był problemu nadmiernej hałaśliwości wagonów szczególnie podczas pokonywania przez nie zakrętów. Użytkowane wagony miały większy rozstaw osi niż pojazdy, dla których projektowana była trakcja szynowa kilka dekad wcześniej. W efekcie podczas jazdy po łuku występowało większe tarcie kołnierza koła o szynę, co w nieunikniony sposób wiązało się z większym hałasem. Aby zmniejszyć nieco jego poziom, już latem 1930 roku dyrekcja przedsiębiorstwa zarządziła częstsze smarowanie szyn w tych miejscach. Używano do tego specjalnej mieszaniny grafitu i smaru ${ }^{36}$. Był to tymczasowy środek zaradczy i też nie do końca właściwie stosowany. Po dwóch latach tych praktyk gazety retorycznie pytały, dlaczego szyny na łukach torów smarowano dopiero po godzinie ósmej, skoro tramwaje jeździły już od godziny szóstej rano ${ }^{37}$.

W trakcie tygodnia ciszy, a także po jego zakończeniu wielu warszawian skarżyło się na łamach prasy na liczne przypadki naruszenia ciszy nocnej, wytykając władzom miasta, że walka z hałasem powinna być prowadzona również na innych frontach. Najczęściej narzekano na działanie służb oczyszczania miasta, które „poza stroną higieniczną" miało także „ujemną stronę fonetyczną z powodu budzenia dozorców, łomotania w bramy, wjeżdżania wozów na dziedzińce lub wynoszenia śmieci w koszach na ulice"38. W listach do prasy warszawiacy skarżyli się, że te dość „archaiczne” wozy jeździły praktycznie od północy do rana, a ich obsługa bynajmniej nie usiłowała zachowywać się cicho ${ }^{39}$. Narzekano na prowadzone nocą remonty, a także na dostawy pieczywa i mleka we wczesnych godzinach porannych. Stałym problemem były również postoje taksówek i dorożek. W porze nocnej,

35
Tamże, s. 6.
Walka z hałasem ulicznym, "Gazeta Polska” 1930 nr 212, s. 4.
Walka z hałasem ulicznym, "Robotnik” 1932 nr 137, s. 4.
Zwalczanie hałasu w centrum miasta, "ABC” 1936 nr 222, s. 1.

Dodatkową uciążliwością był fetor, jaki wozy te "rozsiewają po swej drodze wskutek nieosłaniania wozów i gubienia przez nie z reguły pewnej części zawartości po jezdniach". Zob. J.C. Dwie plagi warszawskie, "Kurier Warszawski” 1936 nr 44, s. 3. 
oczekując na pasażerów, kierowcy i woźnice ucinali sobie dość głośne pogawędki, i to mimo że już rok wcześniej policja warszawska otrzymała polecenie ściślejszych kontroli ich zachowania. Z zapowiedzi kar niewiele robili sobie również amatorzy głośnego słuchania muzyki, a także „męty uliczne”40.

\section{Co dalej?}

Ważnym efektem warszawskiego tygodnia ciszy była konstatacja, że walki z hałasem nie uda się wygrać, dyscyplinując jedynie kierowców, ale że należy zaangażować w ten proces ogół mieszkańców. W tym celu Komisja Główna zainicjowała powołanie Ligi Przeciwhałasowej na wzór podobnych organizacji działających w państwach zachodnich. W jej skład weszły głównie podmioty prawne, jak Związek Miast Polskich, Stowarzyszenie Wielkiej Warszawy, związki właścicieli nieruchomości i lokatorów, związki właścicieli taksówek i kierowców, stowarzyszenia lekarzy i higienistów, rzemieślników, nauczycieli, dziennikarzy, przedsiębiorców budowlanych i pań domu ${ }^{41}$. Niestety, niewiele wiadomo na temat efektów jej działalności.

Pozytywny mimo wszystko wynik tygodnia ciszy stanowił mocny argument w staraniach o zmianę kodeksu drogowego. Dwudziestego siódmego października 1937 roku weszło w życie rozporządzenie Ministerstwa Komunikacji, Spraw Wewnętrznych i Wojskowych regulujące kwestię stosowania sygnalizacji dźwiękowej w ruchu drogowym. Wprawdzie kierowca nadal był zobowiązany do dawania sygnałów dźwiękowych, ale mógł to czynić wyłącznie w okolicznościach, w których zachodziła konieczność ostrzeżenia. Wszelkie nadużywanie było zakazane, podobnie jak stosowanie urządzeń emitujących „silny lub przeraźliwy” dźwięk $k^{\mathbf{4 2}}$.

Rozporządzenie dawało również władzom wojewódzkim prawo ustanawiania własnych regulacji w tym zakresie. Z przywileju tego dość szybko skorzystał wojewoda warszawski, 11 stycznia 1938 roku wprowadzając całodobowy zakaz używania sygnałów dźwiękowych na terenie miasta Warszawy ${ }^{43}$.

40

Odpowiedzialność karnoadministracyjną będq ponosić sprawcy hałasu w porze nocnej, "ABC" 1935 nr 195, s. 2.

Walka z hałasem, „Kurier Warszawski” 1936 nr 43, s. 5; W Warszawie eksperyment się udał, s. 15.

Rozporządzenie ministrów komunikacji, spraw wewnętrznych i spraw wojskowych z dnia 27 października 1937 roku wydane w porozumieniu z ministrem opieki społecznej o ruchu pojazdów mechanicznych na drogach publicznych, DzU MSW, A. II, poz. 258, nr 35, s. 524.

WWarszawie szoferzy nie zatrąbią, "7 groszy" 1938 nr 11, s. 1. 
W tym samym czasie zaczęły obowiązywać przepisy o ciszy nocnej zakazujące głośnego słuchania muzyki i hałaśliwych zabaw po godzinie 23.

Początkowo warszawianie podporządkowali się nowym przepisom dość gładko, ale półtora roku później prasa już narzekała, że „ludzie zaczynają się powoli spod nich wyłamywać". Kierowcy, których stosunkowo łatwo można było zatrzymać i ukarać mandatem, nie stanowili aż takiego problemu i jedynie „od czasu do czasu nieśmiało, lękliwie ktoś użyje klaksonu na ulicy”44. Zdecydowanie trudniej przychodziło respektowanie ciszy nocnej mieszkańcom kamienic, szczególnie latem. W lipcu 1939 roku, kiedy z powodu duchoty wielu warszawian pozostawiało okna otwarte przez całą noc, szczególnie uciążliwi okazali się miłośnicy radia: „nie wystarczają [takiemu] audycje warszawskie i krajowe. Kręci do białego rana, przeskakuje z fali na falę, wysłuchuje hymnów wszystkich państw świata, granych na zakończenie audycji. I nie wystarcza mu forte. On musi nastawiać na fortissime!"45. Najwyraźniej nie podziałała lekcja z lipca 1936 roku, kiedy to na polecenie wojewody za zakłócanie ciszy nocnej zaczęto karać mieszkańców grzywnami w wysokości od 10 do 15 złotych. Początkowo na Pradze, a później w całej Warszawie zaczęły działać lotne patrole z udziałem referentów karno-administracyjnych i policji. Mandaty wręczano w trzech „kategoriach przestępstw: głośniki radiowe, patefony i śpiewy w porze nocnej" ${ }^{46}$.

\section{Hałas pod lupą}

Analiza dziejów walki z hałasem w międzywojennej Polsce ujawnia wprawdzie duży entuzjazm po stronie instytucji samorządowych i organizacji społecznych, ale jednocześnie pokazuje, że podejmowane przez nie działania były pozbawione wszelkich podstaw naukowych. Zwracał na to uwagę dyrektor Zakładu Higieny UJ profesor Witold Gądzikiewicz, od lat zaangażowany w walkę o poprawę warunków sanitarnych w Polsce, przedstawiciel tak zwanej eksperymentalnej szkoły higienistów.

Wychodząc z założenia, że aby „racjonalnie zwalczać jakąś szkodliwość, [...] trzeba przede wszystkim dokładnie ją zbadać", w 1934 roku podjął pierwsze w Polsce studia nad hałasem. Uważał, że „dopiero po zbadaniu

\footnotetext{
44 T.K. Walka z hałasem trwa. Dobry przykład praskiego starosty godny naśladowania, "Czas” 1939 nr 179, s. 8.

45 Tamże.

46 Lotne komisje do walki z hałasem ulicznym w Warszawie, Kurier Wileński" 1936 nr 208, s. 6.
} 
natężenia hałasu i ustaleniu jego szkodliwości można będzie wskazać skuteczne sposoby walki z nim" ${ }^{\text {"47 }}$. Gądzikiewicz nie ukrywał, że inspiracją do zainicjowania tych badań było doświadczenie zagraniczne, przede niemieckie, brytyjskie i amerykańskie. W krajach tych już na początku XX wieku zaczęły powstawać instytuty zajmujące się badaniem hałasu i podejmowano zorganizowane działania w celu ograniczenia jego negatywnego oddziaływania na człowieka.

Już na wstępie zespół Gądzikiewicza zderzył się z ograniczeniami natury finansowej. Podstawowym przyrządem do obiektywnego oznaczania natężenia dźwięku był wówczas miernik ciśnienia akustycznego (niem. Schalldruckmesser) zaprojektowany przez profesora Wyższej Szkoły Technicznej w Dreźnie Heinricha Barkhausena. Przyrząd podawał wartość ciśnienia wywieranego przez falę akustyczną i wyskalowany był w barach (bar), które z kolei łatwo było przeliczyć na decybele $(\mathrm{dB})^{48}$. Koszt takiego urządzenia sięgał pięciu tysięcy złotych, co okazało się przekraczać możliwości finansowe Zakładu Higieny, toteż zakupiono inny przyrząd Barkhausena, tak zwany szumomierz (niem. Geräuschmesser), który umożliwiał pomiar subiektywny. Urządzenie to, produkowane przez firmę Siemens \& Halske, wyskalowane było $\mathrm{w}$ innej jednostce $-\mathrm{w}$ fonach ${ }^{49}$. Zasadniczo obie jednostki były sobie równe, ale decybel używany był (a właściwie nadal jest) do określania pomiaru obiektywnego, a fon - subiektywnego.

Badanie szumomierzem polegało na porównaniu poziomu hałasu z głośnością dźwięku wzorcowego emitowanego przez słuchawkę aparatu. Osoba dokonująca pomiaru musiała przyłożyć słuchawkę do jednego ucha, po czym za pomocą pokrętła zwiększała głośność sygnału. Gdy zrównywał się z hałasem dobiegającym do drugiego, dokonywała odczytu z pokrętła. Operację powtarzano dla drugiego ucha i z obu odczytów obliczano średnią

W. Gądzikiewicz Badanie hałasu ulicznego w miastach polskich, „Zdrowie Publiczne” 1936 nr 7 , s. 619 .

48 Skala decybelowa jest skalą logarytmiczną, która w przybliżeniu odpowiada fizjologii ucha ludzkiego. Zgodnie z prawem Webera-Fechnera za wartość początkową skali wrażenia zmysłowego, jakim jest dźwięk, przyjmuje się ciśnienie akustyczne odpowiadające progowi słyszalności. Na skali logarytmicznej 3 dB oznaczają dwukrotny wzrost natężenia dźwięku, $20 \mathrm{~dB}$ - stukrotny, 30 dB - tysiąckrotny, a stanowiące granicę bólu 130 dB oznaczają wartość 10 bilionów razy większą.

49 H. Gans Hałas, jego wpływ na zdrowie i niektóre sposoby badania stosowane whigjenie , Medycyna" $1934 \mathrm{nr} 18$, s. 618 
arytmetyczną. Różnice pomiędzy wynikami uzyskanymi dla obojga uszu zwykle nie przekraczały 5 fonów ${ }^{50}$.

Zakup urządzenia pozwalającego na subiektywny pomiar natężenia dźwięku, choć wymuszony ograniczonymi zasobami materialnymi zakładu, pochwalał doktor Henryk Gans, jeden z członków zespołu Gądzikiewicza. Jego zdaniem, „higieniście nie tyle powinno zależeć na pomiarach absolutnych wyrażających natężenie głosu [w barach], ile na uzyskaniu takiego przyrządu, który by pozwalał na zróżnicowanie siły głosu w granicach fizjologicznego i patologicznego działania"51.

Gdy w pierwszej połowie lat 30. inicjowano w Polsce badania hałasu, nie tylko standard jednostek i procedura pomiarów były już ustalone. Dzięki dokonaniom zachodnich badaczy poznano w dużym stopniu oddziaływanie dźwięku na zdrowie człowieka. Za bezpieczną granicę higieniści powszechnie uważali poziom 6 o fonów.

Zarówno miernik ciśnienia akustycznego jak i szumomierz pozwalały na pomiar wartości chwilowych, a te mogły zmieniać się z dużą nieregularnością w skali od o do 90 fonów. Tymczasem o uciążliwości dźwięku w dużym stopniu decyduje nie tylko jego głośność, ale również czas trwania. Za najwłaściwszy przyrząd do takich pomiarów Gans uważał tak zwany miernik ilości hałasu (niem. Lärmzähler) Dolda i Thiele'a podający wielkość dawki wprost proporcjonalną do czasu i poziomu natężenia dźwięku ${ }^{52}$.Z publikacji dokumentujących działalność badawczą Zakładu Higieny do czasu wybuchu wojny nie wynika, by przeprowadzono jakiekolwiek badania przy wykorzystaniu tego urządzenia.

50 I. Cwojdzińska Badanie hałasu w kopalniach węgla " "Archiwum Higieny" 1936 nr 1, s. 87.

51 H. Gans Hałas, jego wpływ..., s. 620.

52 Pod koniec lat 20. Hermann Dold i Heinrich Thiele z Instytutu Higienicznego Uniwersytetu w Kilonii podali definicję jednostki wielkości/ilości hałasu (Lärmmengeneinheit/Lärmzahleinheiten), której nadali miano thoryb (grec. Đópußos - hałas) i określili wzorem: 1 thoryb $=1$ fon X 1 min. W 1930 r. opublikowali opis urządzenia do pomiaru tej wielkości; zob. „Gesundheits-Ingenieur” $1930 \mathrm{nr}$ 1, s. 13-14; zob. również polski opis urządzenia: S.W. Thorybometer, "Dom, Osiedla, Mieszkanie" 1930 nr 6, s. 6. W 1939 r. Thiele i Holzberg zaprezentowali ulepszoną wersję urządzenia, zob. H. Thiele, K. Holzberg Ein Beitrag zur Messung des Lärms mit dem verbesserten Lärmzähler von Dold und Thiele, "Zeitschrift für Hygiene und Infektionskrankheiten" 1939 nr 2, s. 125-145. Ostatecznie thoryb się nie przyjął, a dopuszczalna dawka hałasu, określana współcześnie jako poziom ekspozycji na hałas odniesiony do ośmiogodzinnego wymiaru czasu pracy, wynosi $85 \mathrm{~dB}$ i wyraża się w jednostkach 1 Pa2 x s. 
Pierwszą serię systematycznych badań hałasu ulicznego Gans przeprowadził w 1933 roku. Wyposażony w szumomierz Barkhausena ze słuchawką przy uchu jeździł różnymi pojazdami po ulicach Krakowa. Uzyskane wyniki pozwoliły w sposób naukowy uporządkować wiedzę na temat wpływu, jaki na poziom hałasu ulicznego ma rodzaj pojazdu oraz nawierzchni, po jakiej się porusza. Ważna jest również prędkość jazdy. Co było raczej do przewidzenia, najbardziej hałaśliwe okazały się wozy wyposażone w koła o żelaznych obręczach poruszające się po bruku kamiennym - przy $10 \mathrm{~km} / \mathrm{h}$ aparat Barkhausena wskazywał aż 95 fonów. Najlepiej wypadła w tym eksperymencie nawierzchnia asfaltowa - samochód na kołach pneumatycznych, który przy maksymalnej prędkości dopuszczalnej na terenie zabudowanym wynoszącej wówczas $40 \mathrm{~km} / \mathrm{h}$, na bruku powodował hałas o natężeniu 75 fonów, na asfalcie uzyskiwał wynik o 10 fonów niższy. Przy prędkości $20 \mathrm{~km} / \mathrm{h}$ poziom wytwarzanego hałasu spadał do 45 fonów ${ }^{53}$.

Gans mierzył poziom hałasu z pozycji poruszającego się pojazdu. Zdawał sobie sprawę, że natężenie dźwięku docierającego do pieszych na chodnikach bądź do osób pozostających wewnątrz budynków położonych przy ulicach było inne. Badania takie za pomocą wypożyczonego z Zakładu Higieny aparatu przeprowadziła doktor Janina Wisłouch-Smreczyńska, lekarka szkolna z żeńskiego Gimnazjum SS. Urszulanek przy ul. Starowiślnej w Krakowie. Pomiarów dokonała w pomieszczeniach lekcyjnych, starając się określić poziom hałasu docierającego z ulicy, z sali gimnastycznej oraz z warsztatów szkolnych ${ }^{54}$.

W latach 30. XX wieku skrzyżowanie Starowiślnej z ulicą św. Gertrudy, Sienną i Potockiego (obecnie Westerplatte) było ruchliwym węzłem komunikacyjnym. Głównym źródłem hałasu były przecinające się w tym miejscu dwutorowe linie tramwajowe. Wszystkie ulice były brukowane kostką kamienną i jedynie początek ulicy Wielopole, oddzielonej od budynku szkoły niewielkim skwerem, był asfaltowy. Dokonując pomiarów przy zamkniętych oknach, Smreczyńska uzyskała wynik 45-50 fonów w przypadku przejeżdżających tramwajów (z obserwacji wynikało, że w zależności od pory dnia przejeżdżało ich od 40 do 70 na godzinę). Najgłośniejszy był dźwięk dzwonka tramwajowego i przejeżdżającej ciężarówki - hałas dochodził wówczas do 60 fonów. Dla porównania w salach lekcyjnych, których okna wychodziły na

\footnotetext{
53 H. Gans Hałas, jego wpływ na zdrowie i niektóre sposoby badania stosowane whigjenie , "Medycyna" 1935 nr 5, s. 153.

54 J. Smreczyńska O badaniu hałasu w szkole, „Wychowanie Fizyczne” 1936 nr 3-4, s. 120.
} 
wewnętrzne podwórze, ogólny poziom hałasu wynosił 15-20 fonów, a z szumu dawało się jedynie wyróżnić sygnał dzwonka tramwajowego. Zdaniem lekarki niezbędne było podjęcie pilnych starań o zmniejszenie poziomu hałasu docierającego do pomieszczeń szkolnych. Jej zdaniem odpowiedzialność spoczywała przede wszystkim na władzach miejskich, w których mocy było wydanie zakazu używania sygnałów dźwiękowych, zmniejszenie prędkości poruszania się pojazdów oraz poprawienie stanu nawierzchni ulic ${ }^{55}$.

Na początku marca 1936 roku kontynuowano badania hałasu ulicznego tym razem z perspektywy pieszego. Pomiary przeprowadził sam Gądzikiewicz w kilku charakterystycznych punktach Wilna oraz Warszawy, przy czym w pierwszym mieście towarzyszył mu profesor Aleksander Safarewicz, bakteriolog i lekarz higienista, a w stolicy w pomiarach pomagał student politechniki, niejaki Kossowski ${ }^{56}$.

Badania wykazały, że poziom natężenia hałasu ulicznego w Wilnie był na ogół wyższy niż w Warszawie, co tłumaczono złym stanem bruku ulicznego, wykonanego głównie z otoczaków granitowych. Gądzikiewicz zaznaczał jednak, że choć natężenie hałasu na ulicach warszawskich było mniejsze niż w Wilnie, to z racji intensywniejszego ruchu ulicznego w hałas w stolicy odczuwano jako daleko bardziej uciążliwy. Poniekąd zatem słuszne okazało się popularne wówczas w Warszawie powiedzenie, że „gdy «spokojny prowincjusz z Wilenka» przybędzie do stolicy i pochodzi po ulicach z parę godzin, dostaje bólu głowy"57.

$\mathrm{Na}$ to, że skutki oddziaływania hałasu mają w rzeczywistości charakter klasowy, zwracał uwagę Gans. Planując dalszy etap badań, zastanawiał się, na ile zgiełk uliczny powodował wśród mieszkańców miast nie tylko „tak typową dla nich nerwowość ogólną,, ale również pogorszenie słuchu. „Czy tak jest w rzeczywistości - pisał - można by się przekonać przez masowe badania porównawcze wieśniaków, którzy nie są tak narażeni na ciągłe urazy słuchowe, i mieszkańców ruchliwych ulic miejskich"58.

Wyniki badań hałasu prowadzonych w Zakładzie Higieny UJ dość szybko zaczęły przenikać do obiegu naukowego. Na badania Gansa powoływał się między innymi Erwin Haberfeld w swojej pracy nad zmęczeniem

Tamże, s. 121.

W. Gądzikiewicz Badanie hałasu ulicznego..., s. 622.

Hałas uliczny w Wilnie jest o wiele większy niż w Warszawie, "Kurier Wileński” 1936 nr 229, s. 5.

58 H. Gans Hałas, jego wpływ..., s. 156. 
kierowców ${ }^{59}$. Co warto podkreślić, publikacje krakowskich lekarzy należały do pierwszych w kraju opracowań omawiających również kwestie techniczne związane z pomiarem hałasu ${ }^{60}$. Od połowy 1936 roku również gazety codzienne, dotąd opisujące uciążliwość hałasu w sposób wrażeniowy, zaczęły epatować czytelników fonami, wyjaśniając, ile emituje ich taki a taki pojazd poruszając się po takiej czy innej nawierzchni drogowej.

Tymczasem, choć nie uporano się jeszcze z hałasem generowanym przez ruch uliczny, mieszkańcom stolicy zaczęło dawać się we znaki jego kolejne źródło - lotnisko. Prowadząc pomiary w pobliżu pierwszego w kraju portu lotniczego na Mokotowie, Gądzikiewicz stwierdził, że samoloty stały się tam „istnym utrapieniem mieszkańców, często większym nawet niż zwykły hałas uliczny". Pomiary przeprowadzone 6 marca 1936 roku na werandzie domu przy ulicy Juliusza Fałata, tuż obok dziś już nieistniejącego lotniska mokotowskiego, wykazały, że samolot lecący około 200 metrów nad domem wywoływał hałas dochodzący do 85 fonów ${ }^{61}$. A zatem więcej niż konna fura na resorach przejeżdżająca po kocich łbach na ulicy Topolowej, na której tego dnia Gądzikiewicz również rozstawił swoją aparaturę.

\section{Walka wciąż trwa}

Walka z hałasem ulicznym w Polsce rozpoczęła się na dobre w połowie lat 30. $\mathrm{XX}$ wieku. Wzorem rozwiniętych państw zachodnich podjęto próbę administracyjnego ograniczenia uciążliwości ruchu samochodowego, uznano go bowiem za najpoważniejsze zagrożenie dla komfortu akustycznego Polaków. Jednak zarówno wyniki badań przeprowadzonych przez naukowców z Zakładu Higieny UJ, jak i efekty warszawskiego tygodnia ciszy dowiodły, że hałas na ulicach stolicy nie wynikał z jej bogactwa i zaawansowania cywilizacyjnego, lecz wręcz przeciwnie - z biedy i zacofania.

Liczbę samochodów w Warszawie szacowano wówczas na około 60 tysięcy. Niewiele, jeśli porównać z Berlinem czy Londynem, które miały ich po

E. Haberfeld Zmęczenie kierowców samochodowych, "Archiwum Higieny” 1936 nr 1, s. 147.

Metodologia pomiaru hałasu, a nawet szczegółowy opis budowy i funkcjonowania aparatu Barkhausena znalazły się w pierwszej publikacji Gansa z 1934 r. (zob. H. Gans Hałas, jego wpływ..., s. 620), natomiast najwcześniejszy znany artykuł na ten temat autorstwa specjalisty z dziedziny elektrotechniki ukazał się rok później. Zob. S. Darecki O natężeniu hałasu, „Przegląd elektrotechniczny" 1936, nr 10, s. 310-312.

W. Gądzikiewicz Badanie hałasu ulicznego..., s. 624 . 
milion. Gdy w stolicy Polski na siedem nocy ucichły klaksony i trąbki samochodowe, okazało się, że mieszkańcy nadal nie mogą zasnąć, ale z powodu rozklekotanych tramwajów i przestarzałego systemu oczyszczania miasta. Przyrządy pomiarowe jedynie potwierdziły to, co mogło wychwycić nawet niewprawne ucho - na kiepskim bruku hałasowały nie tylko wozy konne na kołach o żelaznych obręczach, ale nawet całkiem nowe samochody.

Walkę z hałasem w międzywojennej Warszawie podjęto, inspirując się przykładem Nowego Jorku, Londynu i Berlina. Nie było to bezmyślne podążanie za "modą". Na warszawskich ulicach rzeczywiście było głośno, a informacje o rezultatach działań zmierzających w kierunku ograniczenia uciążliwości ulicznego hałasu w zagranicznych metropoliach uświadomiły Polakom konieczność zajęcia się tym problemem również w kraju.

Praktycznym efektem prac Komisji Głównej do zwalczania hałasu była reforma ustawodawstwa. Otworzyła ona drogę do kształtowania nowoczesnych nawyków wśród uczestników ruchu drogowego oraz uświadomiła wagę troski o właściwy klimat akustyczny w mieście, na ulicy i w mieszkaniu. Również dorobek naukowy zespołu badawczego Zakładu Higieny nie poszedł na marne, dając solidną podstawę do dalszych studiów z zakresu akustyki oraz bezpieczeństwa i higieny pracy. Wybuch wojny nie pozwolił jednak zweryfikować, jak trwałe były to efekty. Po 1945 roku, jak można sądzić z analizy pierwszych powojennych relacji, walkę z hałasem trzeba było zaczynać od nowa. 


\section{Abstract}

\section{Sławomir Łotysz}

INSTITUTE FOR THE HISTORY OF SCIENCE, POLISH ACADEMY OF SCIENCES

Combatting Street Noise in Interwar Warsaw. Trend or Necessity?

In the interwar period, the fight against noise pollution was as present in Polish society as it was in developed Western countries. Anti-noise committees and leagues emerged, weeks of silence were organised and levels of noise were measured in the streets. Łotysz uses reports from these measurements as well as other textual sources from the epoch to show that the noise in Polish cities was not a measure of progress, but on the contrary of backwardness. The main cause of noise pollution was not an excess of cars, as in the Western cities that served as a benchmark, but the disastrous condition of the streets and tracks, outdated means of transport and archaic road traffic regulations.

\section{Keywords}

Second Polish Republic, noise, city, transport, history 